\title{
Potentially toxic metals of vegetable gardens of urban schools in Lages, Santa Catarina, Brazil
}

\author{
Maria Sueli Heberle Mafra ${ }^{1 *}$ Willian Galdino Lunardi ${ }^{2}(\mathbb{D})$ Ana Emilia Siegloch ${ }^{1}(\mathbb{C}$ \\ Ângela Fonseca Rech ${ }^{3}$ Tássio Dresch $\operatorname{Rech}^{3}\left(\mathbb{D}\right.$ Mari Lucia Campos ${ }^{2}$ (D) \\ Aniela Pinto Kempka ${ }^{4}$ Simone Silmara Werner $^{3} \mathbb{D}$
}

\author{
${ }^{1}$ Programa de Pós-graduação em Ambiente e Saúde, Universidade do Planalto Catarinense (UNIPLAC), 88509-900, Lages, SC, Brasil. E-mail: \\ mshmafra@gmail.com. "Corresponding author. \\ ${ }^{2}$ Centro de Ciências Agroveterinárias (CAV), Universidade do Estado de Santa Catarina (UDESC), Florianópolis, SC, Brasil. \\ ${ }^{3}$ Empresa de Pesquisa Agropecuária e Extensão Rural de Santa Catarina, Estação Experimental de Lages (Epagri/EELages), Lages, SC, Brasil. \\ ${ }^{4}$ Centro de Educação Superior do Oeste (CEO), Universidade do Estado de Santa Catarina (UDESC), Pinhalzinho, SC, Brasil.
}

ABSTRACT: Urban environments are contaminated in many ways with persistent organic and inorganic pollutants as a result of anthropogenic activities, endangering human health and natural resources. The objective of the present study was to evaluate the soil contamination by cobalt (Co), chromium (Cr), copper (Cu), manganese (Mn), nickel (Ni), lead (Pb), and zinc (Zn) in 10 vegetable gardens of urban schools located near or on Botucatu sandstone outcrops of Guarani Aquifer in the urban areas of Lages, Santa Catarina, Brazil. In each garden, three soil samples at each position (in the soil immediately outside and the soil in the garden) were collected at a depth of 0-20 cm. The ISO 11466 method was used to extract the metals. Inductively coupled plasma optical emission spectrometry was used to quantify the elements and certified materials to evaluate the quantities (SRM 2709a - San Joaquin Soil - NIST). To evaluate the data, principal component analyses and cluster analyses were performed. The cluster analysis for the evaluated metals showed that the highest contents of elements were reported in three gardens. Values above the prevention value defined by resolution no. 420/2005 of the National Council for the Environment - Conselho Nacional do Meio Ambiente (CONAMA) - were reported for cobalt in one garden and copper in three gardens; thus, these areas were categorized as Class III areas. Principal component analysis explained $74.7 \%$ of the data and showed the enrichment of some elements within gardens. Key words: environmentally sensitive areas, urban gardens, environmental contamination.

Metais potencialmente tóxicos em hortas escolares na região urbana de Lages, Santa Catarina, Brasil

RESUMO: Ambientes urbanos são contaminados de muitas maneiras com poluentes orgânicos e inorgânicos persistentes como resultado de atividades antrópicas, colocando em risco a saúde humana e os recursos naturais. O objetivo do presente estudo foi avaliar a contaminação do solo por cobalto (Co), cromo (Cr), cobre (Cu), manganês (Mn), níquel (Ni), chumbo (Pb) e zinco (Zn) em 10 hortas de escolas urbanas situadas próximo ou sobre áreas de afloramento de arenito Botucatu do Aquífero Guarani, no município de Lages, Santa Catarina. Em cada horta, três amostras de solo foram coletadas (dentro e fora da horta) na profundidade de 0-20 cm. O método ISO 11466 foi usado para extrair os metais. Utilizou-se espectrometria de emissão óptica com plasma indutivamente acoplado (ICP OES) para quantificar os elementos e materiais certificados (SRM 2709a - San Joaquin Soil - NIST). Para avaliar os dados foi feita a análise dos componentes principais e análise de agrupamento. Pela análise de agrupamento para os metais avaliados observou-se que as maiores concentrações de elementos foram encontradas em três hortas. Valores acima do valor de prevenção (PV) definido pela resolução no. 420/2005 do Conselho Nacional do Meio Ambiente (CONAMA) foram encontrados para Co em uma horta e Cu em três hortas, classificando essas áreas como classe III. A análise de componentes principais explicou 74,7\% dos dados e mostrou o enriquecimento de alguns elementos dentro das hortas.

Palavras-chave: áreas ambientalmente sensiveis, hortas urbanas, contaminação ambiental.

\section{INTRODUCTION}

Urban environments are contaminated with persistent organic and inorganic pollutants as a result of anthropogenic activities. When contents of toxic metal in water, air, or soil exceed established legal threshold and prevention values, they are treated as pollutants (HORTA et al., 2015). At these elevated contents, they represent a health risk to the population, especially in areas where food production activities are taking place, as in the case of urban gardens.

Urbanization and the absence of pollutionmonitoring programs are the main causes of increased contamination levels in urban environments. The main sources of pollution in urban environments included combustion and spillage of fossil fuels, industrial waste, lack of basic sanitation and domestic sewage leaks, and inadequate disposal of solid waste containing 
paints, rubber, and batteries, among other potentially toxic compounds, in vacant lots (MCBRIDE et al., 2014; UWIZEYIMANA et al., 2017).

Metals such as $\mathrm{Co}, \mathrm{Cr}, \mathrm{Cu}, \mathrm{Mn}, \mathrm{Pd}$, and $\mathrm{Zn}$ are high-density elements and have been associated with contamination processes in different ecosystems. Some metals, such as $\mathrm{Cu}, \mathrm{Cr}, \mathrm{Fe}, \mathrm{Mg}, \mathrm{Mn}, \mathrm{Ni}$, and $\mathrm{Zn}$, are essential for living organisms because of their important role in coenzymes, but they are required in low contents. When present in high contents, they can become toxic. However, the metalloid As and the metals $\mathrm{Al}, \mathrm{Cd}, \mathrm{Cr}$, and $\mathrm{Pb}$ do not have any biological functions, and $\mathrm{As}, \mathrm{Cd}, \mathrm{Cr}$, and $\mathrm{Pb}$ are highly toxic, even at low contents (UWIZEYIMANA et al., 2017; OLIVEIRA, 2009).

Soils may contain toxic metals from various origins. Some elements are inherited directly from the lithosphere (mother material). Anthropogenic elements are all elements deposited in soils as a direct or indirect result of human activities (KABATA-PENDIAS, 2011). Population growth in urban centers along with agricultural and industrial growth generate large amounts of waste, which cause the contents of these elements to exceed natural contents in different environments (HUGEN, 2010, 2013; TSOLOVA et al., 2014).

Soil contamination by these metals occurs because of the existence of bioavailable forms in soil solution. In soluble or exchangeable form, toxic metals can be absorbed by the plants that accumulate them in their tissues, which in turn can be introduced into the food chain (CRISTALDI et al., 2017; GHAYORANEH and QISHLAQI, 2017). While in exchangeable form, the metals can be leached and enter underground water bodies. Aquifer recharge areas, such as the Guarani Aquifer in the urban areas of Lages, Santa Catarina, Brazil, can be irreversibly contaminated depending on the contaminant load released into the environment.

Agricultural and urban activities can irreversibly contaminate environmentally sensitive areas. A significant recharge area of the Guarani Aquifer is located in housing and industrial districts in Lages, but the municipality still lacks planning policies to preserve this important water resource (MAZZOLLI and EHRHARDT-BROCARDO, 2013).

The use of urban soils to develop community gardens or school gardens can have many advantages. However, if developed without prior study and mapping of contaminated areas, these soils can pose a risk to human health. In the present study, the hypothesis supported was that school gardens in the urban area in the city of Lages (SC) would be contaminated with potentially toxic metals. Thus, the objective of this study was to evaluate the soil contamination by $\mathrm{Co}, \mathrm{Cr}, \mathrm{Cu}, \mathrm{Mn}, \mathrm{Ni}, \mathrm{Pd}$, and $\mathrm{Zn}$ in 10 school vegetable gardens located near or on Botucatu sandstone outcrops of the Guarani Aquifer, in the urban area of Lages, Santa Catarina.

\section{METHODOLOGY}

The study was conducted in the city of Lages, SC (Latitude: $-27^{\circ} 48^{\prime} 58^{\prime \prime} \mathrm{S}$; Longitude: $-50^{\circ}$ 19'34" W; Altitude: $916 \mathrm{~m}$ ), located in the Canoas river basin in the plateau of the state of Santa Catarina, southern Brazil. The municipality has approximately 154,000 inhabitants, of which approximately $98 \%$ live in urban areas (IBGE, 2010).

Ten urban school gardens belonging to municipal and state schools were selected for investigation (Table 1). Only gardens located near or on the outcrop areas of the Guarani Aquifer were selected. Soil samples were collected in April 2017. Figure 1 shows the geographical location of the studied gardens identified with numbers.

In each vegetable garden, two sampling transects were placed, one inside and one outside the garden. Each transect was subdivided into three segments, each generating a sample composed of five subsamples. In total, six samples were collected per garden. Soil samples were collected at a depth of $0-20 \mathrm{~cm}$, dried at $60{ }^{\circ} \mathrm{C}$, milled and sieved to remove coarse materials, and analyzed individually.

To extract and analyze contents of the metals $\mathrm{Co}, \mathrm{Cr}, \mathrm{Cu}, \mathrm{Mn}, \mathrm{Ni}, \mathrm{Pb}$, and $\mathrm{Zn}$ in the soil samples, the ISO 11466 method from 1995 was used. One gram of the sample was initially placed

Table1 - Geographical coordinates of the vegetable gardens.

\begin{tabular}{|c|c|}
\hline Vegetable gardens & Geographical coordinates \\
\hline 1 & 27॰49’36”S/50॰21'39”O \\
\hline 2 & 27॰48'19”S/50॰22’41"O \\
\hline 3 & $27 \circ 50 ’ 31 ” S / 50 \circ 20 ’ 34$ 'O \\
\hline 4 & 27॰49'30"S/50॰21'13"O \\
\hline 5 & 27॰50’15”S/50॰20’13"O \\
\hline 6 & $27 \circ 50 ’ 45 " \mathrm{~S} / 50 \circ 21$ '19"O \\
\hline 7 & 27॰49'52”S/50॰19'52”O \\
\hline 8 & 27॰49’26”S/50॰20’33”O \\
\hline 9 & $27 \circ 49^{\prime} 47^{\prime \prime} \mathrm{S} / 50 \circ 20^{\prime} 50$ "O \\
\hline 10 & 27॰49'49”S/50॰21'42”O \\
\hline
\end{tabular}




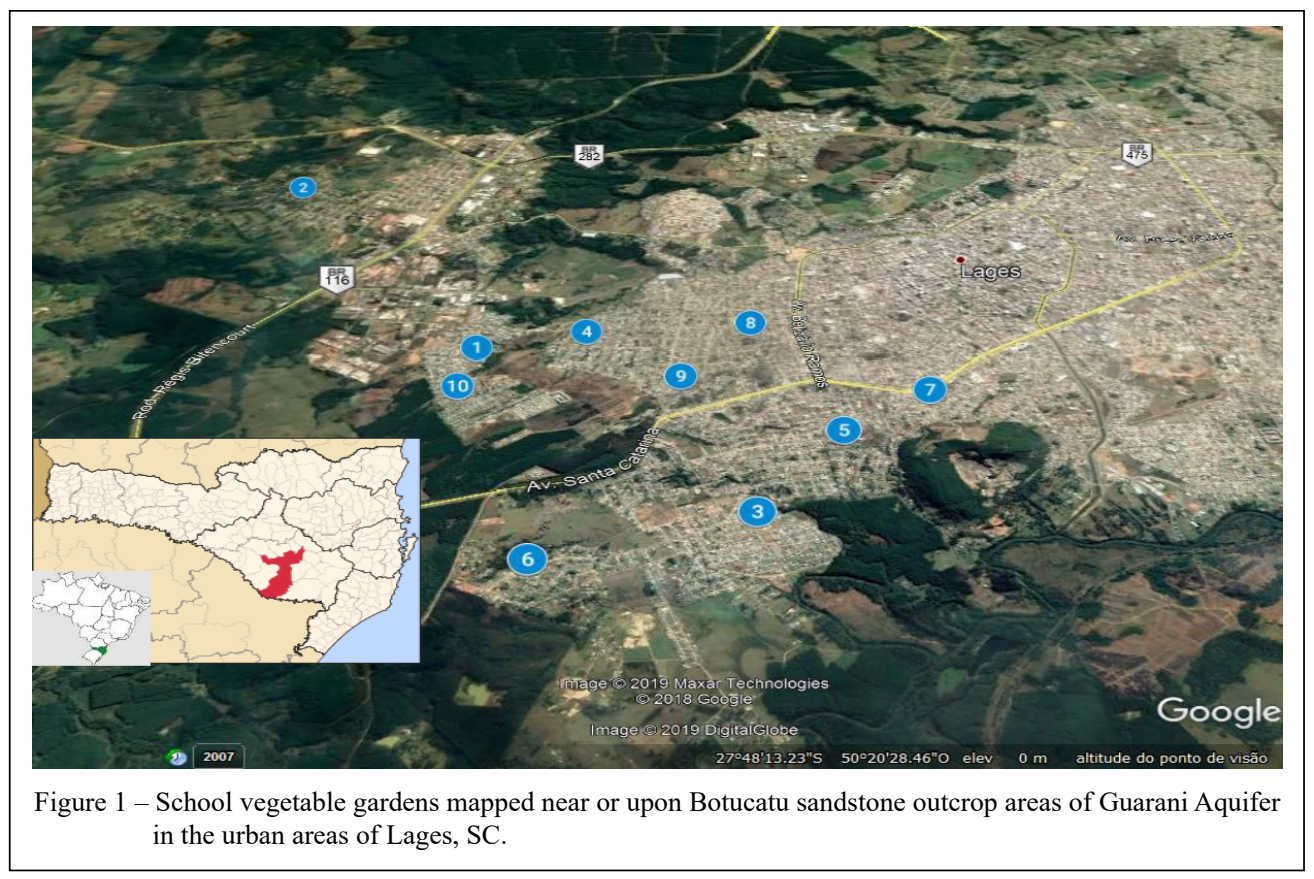

in a digestion tube. Afterward, $0.7 \mathrm{~g}$ of water was added, followed by $9.4 \mathrm{~mL}$ of aqua regia, and it was allowed to stand for $16 \mathrm{~h}$ at room temperature. Then, the sample was heated in a digestion block to $90^{\circ} \mathrm{C}$ for $2 \mathrm{~h}$. Finally, the sample was filtered at room temperature, and the volume was increased to $50 \mathrm{~mL}$ using ultrapure water. The hydrochloric acid $37 \%$ and the nitric acid (65\%) used in the preparation aqua regia were Merck and meet reagent, $\mathrm{pH}$ European and ISO standards. All extractions were performed in duplicate to calculate laboratory error. In each battery, a National Institute of Standards and Technology (NIST) reference sample San Joaquin Soil SRM 2709 and five blank samples were included to calculate the limits of analytical detection.

The content of the assessed elements was analyzed using inductively coupled plasma optical emission spectrometry (ICP-OES; Optima 8300, Perkin Elmer). Specsol's multi elemental pattern (NIST Test \#: 822 / 275197-07) was used to prepare the standard curve. The following wavelengths were used to analyze the elements: Co $(230.79 \mathrm{~nm}), \mathrm{Cr}$ (267.72 nm), Cu (327.39 nm), Mn (257.61 nm), Ni $(231.60 \mathrm{~nm}), \mathrm{Pb}(220.35 \mathrm{~nm})$, and $\mathrm{Zn}(206.20 \mathrm{~nm})$. The following standard curve correlation coefficients were obtained for the evaluated metals: Co (0.9998), $\mathrm{Cr}$ (0.9999), Cu (0.9999), Mn (0.9998), Ni (0.9997), $\mathrm{Pb}$ (0.995), and Zn (0.9999) (Table 2).

The limit of detection (LOD)was determined using the equation (APHA, 2005), where $f d$ is the dilution factor for the samples, $M$ is the mean of the blanks test results, $t$ is the t-student value for a $95 \%$ confidence interval as a function of the number of degrees of freedom of repeated measurements, and $s$ is the standard deviation of the blank test results. Table 3 shows the levels for the reference samples, which were determined by ICP-OES after extraction using the ISO 11466 method (ISO, 1995). The figure also shows the certified levels for the reference sample SRM 2709 for the elements $\mathrm{Co}, \mathrm{Cr}, \mathrm{Cu}, \mathrm{Mn}, \mathrm{Pb}, \mathrm{Ni}$, and $\mathrm{Zn}$.

Table 2 - Instrument conditions parameters.

\begin{tabular}{lc}
\hline Parameter & Value \\
\hline Instrument & Optima 8300 ICO OES \\
Nebulizer & Scott \\
Spray chamber & Cross Flow \\
Torch & Single Slot Quartz Torch \\
Injetor & 2.0 mm alumina \\
\hline Power $(\mathrm{W})$ & 1300 \\
Plasma Gas $\left(\mathrm{L} \mathrm{min}^{-1}\right)$ & 10.0 \\
Aux Gas $\left(\mathrm{L} \mathrm{min}^{-1}\right)$ & 0.4 \\
Neb Gas $\left(\mathrm{L} \mathrm{min}{ }^{-1}\right)$ & 0.7 \\
$\begin{array}{l}\text { Sample uptake rate } \\
(\mathrm{mL} \mathrm{min}\end{array}$ & 1.5 \\
\hline
\end{tabular}

Ciência Rural, v.50, n.3, 2020. 
Table 3 - Determined $\left(\mathrm{mg} \mathrm{kg}^{-1}\right)$ and certified contents of elements analyzed for reference sample Standart reference method (SRM) San Joaquin soil 2709 and limit of detection (LD).

\begin{tabular}{|c|c|c|c|c|}
\hline Element & Determined Content & Total certified contente (SRM 2709) & Certified leachate content & LD \\
\hline $\mathrm{Co}$ & $9.8 \pm 0.9$ & $13.4 \pm 0.07$ & $10-15$ & 0.6 \\
\hline $\mathrm{Cr}$ & $82.5 \pm 6.5$ & $130 \pm 4$ & $60-115$ & 0.7 \\
\hline $\mathrm{Cu}$ & $40.8 \pm 7.9$ & $34.6 \pm 0.7$ & $26-40$ & 4.7 \\
\hline $\mathrm{Mn}$ & $502.0 \pm 40.3$ & $538 \pm 17$ & $360-600$ & 0.4 \\
\hline $\mathrm{Ni}$ & $64.5 \pm 6.7$ & $88 \pm 5$ & $65-90$ & 1.1 \\
\hline $\mathrm{Pb}$ & $19.1 \pm 12.1$ & $18.9 \pm 0.5$ & $12-18$ & 8 \\
\hline $\mathrm{Zn}$ & $77.4 \pm 11.3$ & $106 \pm 3$ & $87-120$ & 9.1 \\
\hline
\end{tabular}

Resolution $n^{\circ} .420 / 2009$ from CONAMA was used for soil reference values for $\mathrm{Co}, \mathrm{Cr}, \mathrm{Cu}, \mathrm{Mn}$, $\mathrm{Ni}, \mathrm{Pb}$, and Zn. Resolution $\mathrm{n}^{\circ}$. 420/2009 (BRASIL, 2009) establishes guidelines for soil and groundwater quality, proposing prevention values (PVs) and investigation values (IVs) for residential, agricultural, and industrial areas.

The Resolution $n^{\circ}$. 420/2009 establishes the following classes of soil quality according to the content of chemical substances in the soil: Class 1 soils in which the contents of chemical substances are smaller than or equal to the quality reference value (QRV); Class 2 - soils in which the contents of at least one chemical substance is greater than the QRV and smaller than or equal to the PV; Class 3 soils in which the contents of at least one chemical substance is greater than PV and smaller than or equal to the IV); and Class 4 - soils in which the content of at least one chemical substance is greater than IV (BRASIL, 2009).

Based on this resolution, HUGEN (2010) established a QRV for $\mathrm{Cr}, \mathrm{Cu}, \mathrm{Ni}, \mathrm{Pb}$, and $\mathrm{Zn}$, and SUPPI (2018) established a QRV for Co and Mn in Santa Catarina State. From the cited authors, the soil groups closest to the studied area were selected, and they were the parameters used to compare the results obtained in this study.

A principal components analysis was performed to show the relationship between 10 school vegetable gardens and the content of the evaluated elements. To avoid scale measurement effects, the variables were centralized and scaled. A graphical representation of the observed individuals and variables in relation to the components was constructed in addition to the ellipses of confidence (95\%) for each sample, considering the garden and position (in the soil immediately outside and the soil in the garden) using the ellipse package (MURDOCH and CHOW, 2013). To verify the existence of groups with different content values of toxic metals, cluster analysis considering the Euclidean distance and Ward method (WARD, 2012), with the Lance-Williams update formula (1967), was used (LANCE and WILLIAMS, 1967). All analyses were performed using $\mathrm{R}$ software version 3.4.2 (R CORE TEAM, 2017).

\section{RESULTS}

The mean content values of the elements are shown in Figure 2. The urban Gardens 1, 2, and 10 had the highest content of $\mathrm{Co}, \mathrm{Cr}, \mathrm{Cu}, \mathrm{Mn}$, and Ni. Garden 7 had the highest Mn in its soil. Gardens 5 and 9 had a higher $\mathrm{Pb}$ content in the soil immediately outside and the soil in the garden. Garden 10 had higher $\mathrm{Pb}$ inside. Garden 10 showed the largest spatial variation (observed by the standard deviation, Figure 2) for the elements $\mathrm{Co}, \mathrm{Cu}, \mathrm{Mn}$, and $\mathrm{Ni}$.

In this study, contents exceeding the QRV for the state of Santa Catarina were observed for Co and $\mathrm{Cr}$ in one garden each, $\mathrm{Cu}$ in eight gardens, $\mathrm{Mn}$ in all of the gardens, $\mathrm{Ni}$ in eight gardens, $\mathrm{Pb}$ in three gardens, and $\mathrm{Zn}$ in six gardens.

Based on the Resolution $n^{\circ}$. 420/09 from CONAMA, one garden had a content of $\mathrm{Co}$ and three gardens had contents of $\mathrm{Cu}$ higher than the established PVs.

Soils of seven gardens were classified as Class II, whereas those of three gardens (1, 2, and 10) were classified as Class III. Class I or IV soils were not found for the evaluated parameters.

Cluster analysis (Figure 3) of the urban school gardens showed the formation of three groups 


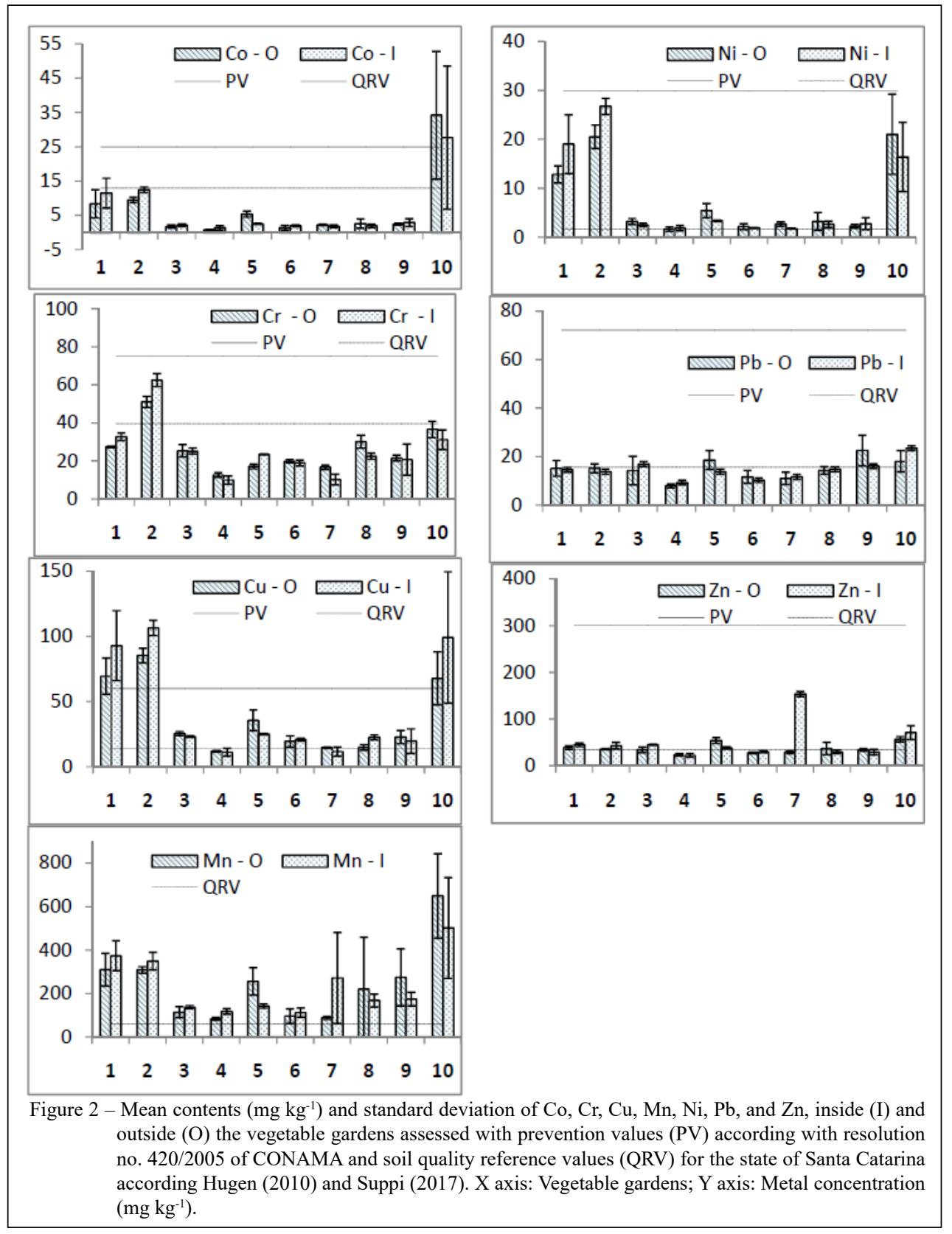

with distinct content of toxic metals among the groups: the first group with Gardens 1,2, and 10; the second group with the Gardens 3, 5, 8, and 9; and the third group with Gardens 4, 6, and 7. Groups were obtained in such a way that the distance between them was as large as possible. This analysis showed that the highest contents of toxic elements were found in the first group.

Through the principal component analysis (Figure 4), it was possible to explain $78.6 \%$ of the variation in the metal content data using only two components, where $60.5 \%$ of the data variation was explained by the $\mathrm{PC} 1$ component and $18.1 \%$ by the PC2 component.

The greatest contributions to the $\mathrm{PC} 1$ axis formation were those of $\mathrm{Ni}, \mathrm{Cu}, \mathrm{Mn}, \mathrm{Co}$, and $\mathrm{Cr}$, which is a negative relation, while $\mathrm{Zn}$ (negative relation) most contributed to the formation of the $\mathrm{PC} 2$ axis (Figure 4). Thus, Gardens 1, 2, and 10 located in the second and third quadrants were characterized 


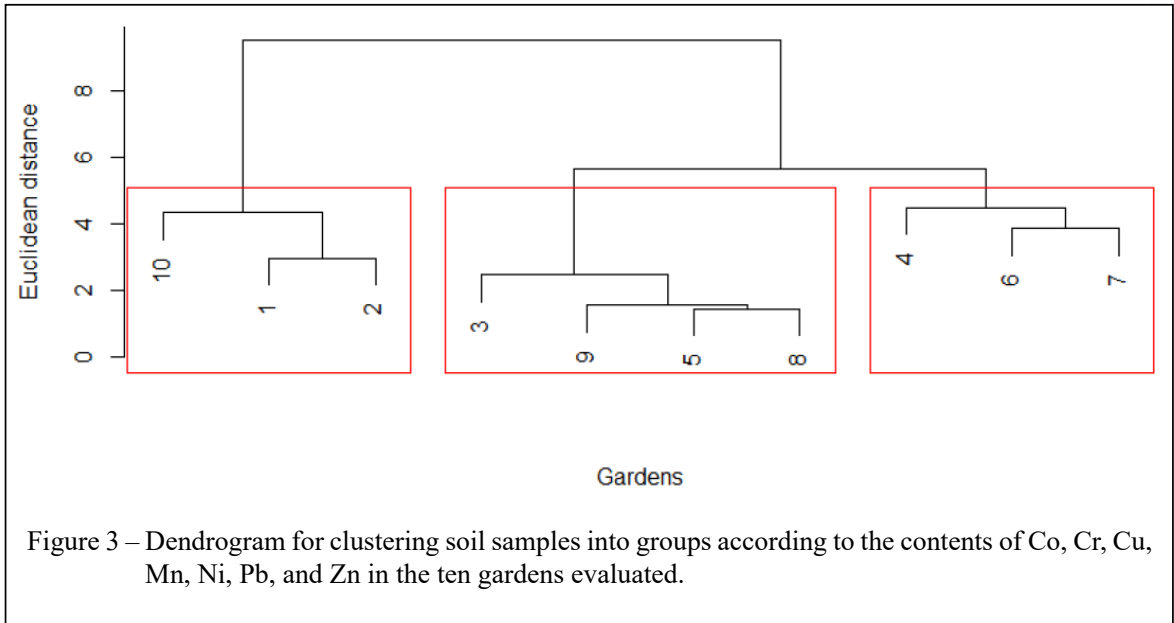

by a higher content of the $\mathrm{Ni}, \mathrm{Cu}, \mathrm{Mn}, \mathrm{Co}$, and $\mathrm{Cr}$ variables, while others vegetable gardens had a lower content of toxic metals.

Using the $95 \%$ confidence ellipses in the principal component analysis in Figure 4(a), it was possible to observe significant differences between Gardens 1, 2, 4, 5, 7, and 10. The analysis indicated that Garden 2 was enriched with the elements $\mathrm{Cr}$, $\mathrm{Cu}$, and Ni. Moreover, in Gardens 1 and 10, there was an enrichment of $\mathrm{Co}$ and $\mathrm{Cu}$, and, in Garden 7 , there was an enrichment of $\mathrm{Zn}$ (Figure 4). In addition, in this study, there was no difference between the soil immediately outside and the soil in the gardens.

\section{DISCUSSION}

Most of the analyzed elements were below the values of prevention, but many were exceeding the QRV, which characterizes soil contamination. The QRV reflects the average natural content of the elements, indicating situations of non-contamination (HUGEN, 2010; KABATA-PENDIAS, 2011; SUPPI, 2018). Contents of $\mathrm{Co}, \mathrm{Cr}, \mathrm{Cu}, \mathrm{Mn}$, and $\mathrm{Ni}$ were higher

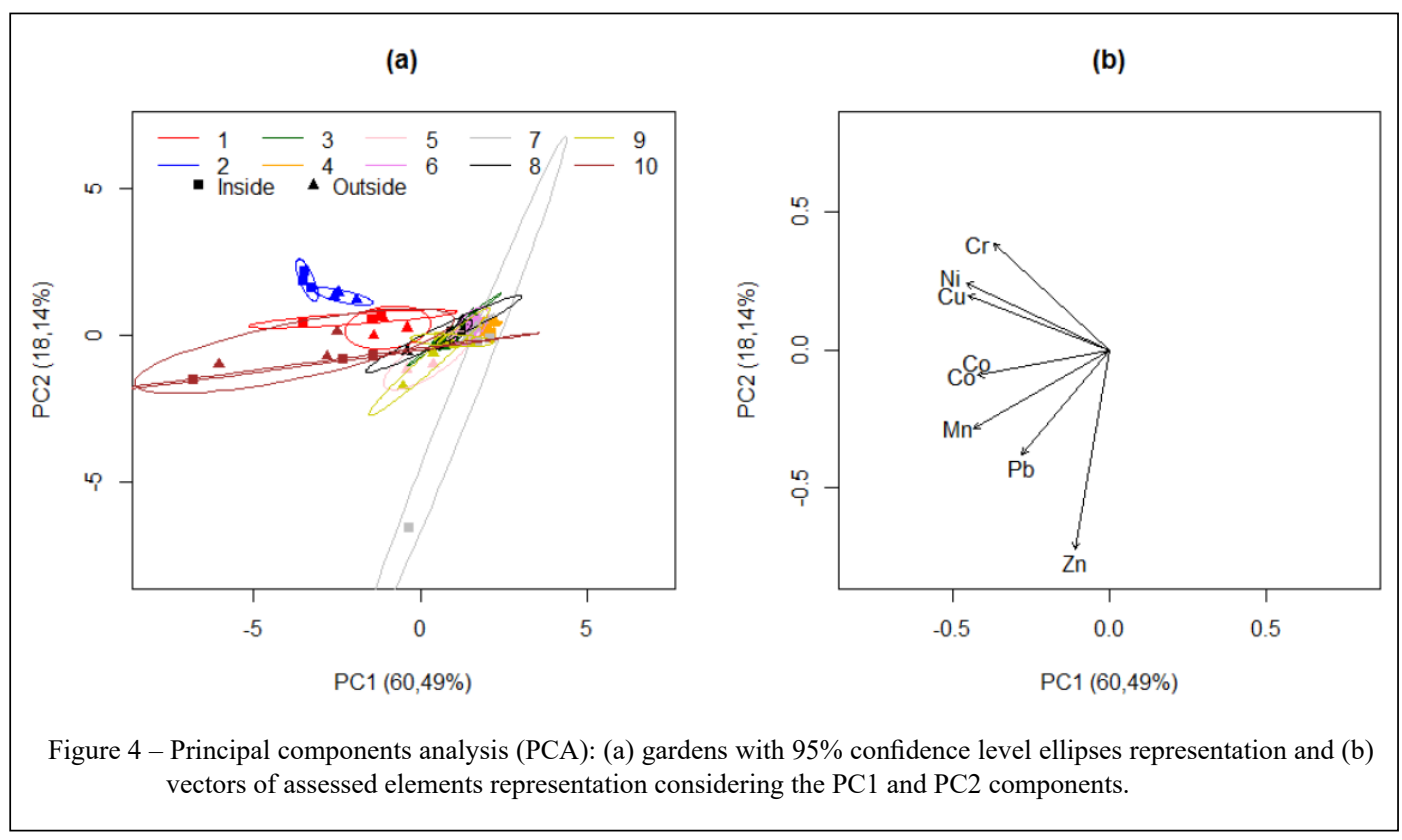

Ciência Rural, v.50, n.3, 2020. 
than the QRV in urban gardens with spatial variation, which is evidenced by the standard deviation. This may be indicative of the use of this area to discard material such as batteries before it became a school vegetable garden. The disposal of batteries in the environment can increase the levels of these elements in the soil (ESPINOSA et al., 2004;).

Based on the CONAMA resolution, the soils of seven vegetable gardens (Gardens 3, 4, 5, 6, 7, 8 , and 9) were classified in class II and three gardens (Gardens 1,2, and 10) in Class III according to the toxic metals analyzed. When Class III soils are reported, the CONAMA legislation requires the identification of the potential source of contamination, assessment of the natural occurrence of the substance, control of the sources of contamination, and monitoring of the soil and groundwater quality. In this sense, an ecotoxicological study in the areas of Gardens 1, 2, and 10 would be recommended to analyze the adverse effects of the pollutants on the garden and plants. These gardens (1, 2 and 10) which belong to the first group in the cluster analysis result, have in common the proximity to an industrial area in Lages. Although, most of the elements did not reach prevention values, contents exceeding the QRV limit and near the PV indicated soil contamination by anthropic activities and deserve attention because of the high toxicity of some metals. Bioavailability of toxic metals in the soil makes it possible for these elements to enter the food chain and affect human health (CHARY et al., 2008; BRASIL, 2009; MAGNA et al., 2013).

The highest contamination of $\mathrm{Cr}, \mathrm{Co}, \mathrm{Cu}$, and $\mathrm{Ni}$ found in Gardens 1, 2, and 10 can be associated with the fact that these gardens are located in or near the industrial district of Lages, SC. EVSEEV and KRASOVSKAYA (2017) observed an increase in heavy metals $(\mathrm{Cu}, \mathrm{Ni}, \mathrm{Co}, \mathrm{Pb}$, and $\mathrm{Zn})$ in different regions of northern Russia within the superficial layers of the ground near industrial areas up to $20 \mathrm{~km}$ from the source of pollution, which exceeded 10 to 100 times the local reference values. CLARKE et al. (2015) also observed higher levels in older neighborhoods of Los Angeles, California, in addition to observing increased levels close to highways. Similarly, PINTO et al. (2011) evaluated five urban gardens along highways with high traffic of cars and three nonurban vegetable gardens, in Braga (Portugal), where they observed contents far exceeding the local limits (Regulation No. 1881/06 of the European Commission) for $\mathrm{Pb}, \mathrm{Cd}$, and $\mathrm{Zn}$ in the soil and in vegetable tissue, especially in urban gardens.

The soil contamination observed by $\mathrm{Cr}$ in Garden 2 and $\mathrm{Cu}$ in Gardens 1, 2, and 10, may have originated from treated wood waste with chromated copper arsenate or similar content (BRAND et al., 2006; VIDAL et al., 2015), and, when burned, this treated wood releases pollutants from the elements $\mathrm{As}, \mathrm{Cu}$, and $\mathrm{Cr}$.

Moreover, these contaminations can be derived from the disposal of waste containing batteries at the sites analyzed. Batteries contain these elements, and when the batteries are discarded in vacant lots, the elements are released into the ground. This hypothesis was evidenced by the presence of discarded batteries in many places during soil sampling. This is because the population is unaware of the risks arising from the improper disposal of batteries in places such as vacant lots along with regular trash, as reported by KEMERICH et al. (2012). Finally, and most troublingly, the three points $(1,2$, and 10), evidenced in cluster analysis, that composed the group of gardens most contaminated with toxic metals in this work are on the direct recharge range of the outcrop of Botucatu Sandstone that encloses the Guarani Aquifer. This range is so named because it represents the places where the rainwater infiltrates, feeding the saturated zone without major obstacles, because there is no rocky package to cross. The high natural vulnerability of the direct recharge areas of the aquifer in question places them in a high exposure risk zone with respect to contamination of both the water table and the deep sheets (GOMES et al., 2006).

These results already reflect the effects of the irregular urban expansion studied by MAZZOLLI and EHRHARDT-BROCARDO (2013). It is necessary to develop planning strategies, especially preventive ones that take into account the use and occupation of the soil.

\section{CONCLUSION}

Three school vegetable gardens of the 10 studied in the urban environment located near or on outcrop areas of the Guarani Aquifer had soil contents of some potentially toxic metals that exceeded the PV values. The content of Co in the soil of Garden 10 and $\mathrm{Cu}$ in the soil of the Gardens 1,2 , and 10 exceeded the PV defined by resolution no. 420/2009 of CONAMA. Thus, these areas were categorized as Class III. In some gardens, contents of some toxic elements exceeded the QRV defined for this region; and although, they did not exceed the limits of PV, some contents were very close to the limits of PV. Results obtained indicated the need for soil quality monitoring in the studied areas. The authors suggested an ecotoxicological study in areas in which 
the contents of potentially toxic elements exceed the PV defined in the CONAMA 420/09 legislation, especially because contamination in these are areas could lead to contamination of the Guarani Aquifer.

\section{ACKNOWLEDGEMENTS}

This study was funded by the Fundação de Amparo à Pesquisa e Inovação do Estado de Santa Catarina (FAPESC) by providing funds for the execution of the project through the Rede Aquífero Guarani/Serra Geral under FAPESC number 2015TR1069. And was funded in part by the Coordenação de Aperfeiçoamento de Pessoal de Nível Superior (CAPES) with the scholarship of the first author (PNPD/CAPES), and by the Empresa de Pesquisa Agropecuária e Extensão Rural de Santa Catarina (EPAGRI) with the technical support and the use of their facilities.

\section{DECLARATION OF CONFLICT OF INTERESTS}

The authors declare no conflict of interest. The founding sponsors had no role in the design of the study; in the collection, analyses, or interpretation of data; in the writing of the manuscript, and in the decision to publish the results.

\section{AUTHORS' CONTRIBUTIONS}

All authors contributed equally to the conception and writing of the experiments. WGL, MSHM, AES and AFR performed the experiments and laboratory analyzes. APK, MLC and TDR provided guidance and technical and operational support. SSW conducted statistical tests of experimental data. All authors critically reviewed the manuscript and approved the final version.

\section{REFERENCES}

AMERICAN PUBLIC HEALTH ASSOCIATION - APHA. Standard methods for the examination of water and waster. 21 ed. Washington, 2005. 1083p.

BRAND, M.A. et al. Present situation of research and utilization of new products for wood preserving treatment. FLORESTA, v.36, n1, p.129-138, 2006. Available from: <https://revistas.ufpr. br/floresta/article/download/5600/4083>. Accessed: Jul. 18, 2017. doi: $10.5380 /$ rf.v36i1.5600

CHARY, N.S. et al. Assessing Risk of Heavy Metals from Consuming Food Grown on Sewage Irrigated Soil and Food Chain Transfer. Ecotoxicol Environ Saf, v.69, n.3, p.513-524, 2008. Available from: <https://www.sciencedirect.com/science/article/ abs/pi i/S0147651307000851>. Accessed: Jul. 20, 2017. doi: 10.1016/j.ecoenv.2007.04.013.

CLARKE, L.W. et al. Urban legacies and soil management affect the concentration and speciation of trace metals in Los Angeles community garden soils. Environ Pollut. v.197, p.1-12, 2015. Available from: <https://www.sciencedirect.com/science/article/ pii/S0269749114004692>. Accessed: Jul. 20, 2017. doi: 10.1016/j. envpol.2014.11.015.

BRASIL - Conselho Nacional do Meio Ambiente - CONAMA. Resolução 420, de 28 de dezembro de 2009. Available from: <http://www.mma.gov.br/port/ conama/legiabre. cfm?codlegi $=620>$. Accessed: Jul. 18, 2017.

CRISTALDI, A. et al. Phytoremediation of contaminated soils by heavy metals and PAHs. A brief review. Environmental Technology \& Innovation. v.8, p.309-326, 2017. Available from: $\quad<$ https://www.sciencedirect.com/science/article/abs/pii/ S2352186417300330>. Accessed: Jul. 20, 2017. doi: 10.1016/j. eti.2017.08.002.

ESPINOSA, D.C.R. et al. Brazilian policy on battery disposal and its practical effects on battery recycling. J Power Sources. v.137, n.134-139, 2004. Available from: <https://www.sciencedirect.com/ science/article/abs/pii/S0378775304002721>. Accessed: Jul. 20, 2017. doi: 10.1016/j.jpowsour.2004.02.023.

EVSEEV, A.V.; KRASOVSKAYA, T.M. Toxic metals in soils of the Russian North. J Geoch Expl. v.174, p.128-131, 2017. Available from: <https://www.sciencedirect.com/science/article/ pii/S037567421530008X > Accessed: Jul. 17, 2017. doi: 10.1016/j. gexplo.2015.05.018.

GHAYORANEH, M.; QISHLAQI, A. Concentration, distribution and speciation of toxic metals in soils along a transect around a $\mathrm{Zn} / \mathrm{Pb}$ smelter in the northwest of Iran. J Geoch Expl. v.180, p.1-14, 2017. Available from: <https:/www.sciencedirect.com/ science/article/pii/S0375674216303156> . Accessed: Jul. 21, 2017. doi:10.1016/j.gexplo.2017.05.007.

GOMES, M.A.F. et al. Caracterização das áreas de afloramento do Aquífero Guarani no Brasil: base para uma proposta de gestão sustentável. Embrapa Meio Ambiente:Jaguariúna, Documentos, 2006. 20p. Available from: <https://ainfo.cnptia. embrapa.br/digital/bitstream/CNPMA/6298/1/documentos_52. pdf>. Accessed: Jul. 21, 2017. ISSN 1516-4691.

HORTA, A. et al. Potential of integrated field spectroscopy and spatial analysis for enhanced assessment of soil contamination: A prospective review. Geoderma. v.241-242, p.180-209, 2015. Available from: <https://www.sciencedirect.com/sdfe/reader/ pii/S0016706114004182/pdf>. Accessed: Jul. 20, 2017. doi: 10.1016/j.geoderma.2014.11.024.

HUGEN, C. Valores de Referência para Teores de $\mathbf{C r}, \mathbf{C u}, \mathbf{N i}$, Pb e Zn em Solos do Estado de Santa Catarina. Dissertação (Mestrado) - Lages: Universidade do Estado de Santa Catarina Centro de Ciências Agroveterinárias; 2010.

HUGEN, C.et al. Teores de $\mathrm{Cu}$ e $\mathrm{Zn}$ em perfis de solos de diferentes litologias em Santa Catarina. Rev. bras. Eng. Agríc. Ambient. v.17, p.622-628, 2013. Available from: $<$ http://www.scielo.br/scielo.php?script=sci arttext\&pi$\mathrm{d}=\mathrm{S} 1415-43662013000600008 \& \operatorname{lng}=\mathrm{en} \& \mathrm{nrm}=\mathrm{iso} \& \mathrm{t} \operatorname{lng}=\mathrm{pt}>$. Accessed: Jul. 20, 2017. doi: 10.1590/S1415-4366.

IBGE. Instituto Brasileiro de Geografia e Estatística Censo demográfico (IBGE). Available from: <https://ww2.ibge.gov.br/home/ estatistica/populacao/censo2010/default. Shtm>. Accessed: Jan. $18,2018$.

KABATA-PENDIAS, A. Trace elements in soils and plants.4th ed. CRC Press:Boca Raton, 2011, 534p. ISBN 978-1-4200-9368-1.

KEMERICH et al. Descarte indevido de pilhas e baterias: a percepção do problema no município de Frederico Westphalen - RS. Rev. Elet. em Gestão, Educação e Tecnologia Ambiental. v.8, 
n.8, p.1680-1688, 2012. Available from: <https://periodicos.ufsm. br/index.php/reget/article/view/6319>. Accessed: Dec, 20, 2017. doi: $10.5902 / 223611706319$.

ISO (International Organization for Standardization) 11466:1995 - Soil quality - Extraction of trace elements soluble in aqua regia.1995. Available from: <https://www.iso.org/obp/ ui/\#iso:std:iso:11466:ed-1:v1:en>. Accessed: Jan. .18,2018.

LANCE, G.N.; WILLIAMS, W.T. A. General Theory of Classificatory Sorting Strategies. 1. Hierarchical Systems. Computer Journal. v.9, n.4, p.373-380, 1967. Available from: <https://academic.oup.com/comjnl/articlepdf/9/4/373/1101470/9-4-373.pdf>. Accessed: Jul. 01, 2018. Doi: 10.1093/comjn1/9.4.373.

MAGNA, G.L.M. et al. Chumbo e cádmio detectados em alimentos vegetais e gramíneas no município de Santo Amaro-Bahia. Quim. Nova, v.36, n.7, p.989-997, 2013. Available from: $\quad<$ http://www.scielo.br/scielo.php?script=sci arttext\&pid $=$ S0100-40422013000700012>. Accessed: Jul. 01, 2018. doi: 1590/S0100-40422013000700012.

MAZZOLLI, M.; EHRHARDT-BROCARDO N.C.M. Irregular occupation in areas of Guarani aquifer recharge and riparian vegetation in Lages-SC. GEOSUL. v.28, n.55, p.163-180, 2013. Available from: <https://periodicos.ufsc.br/index.php/geosul/ article/ view/2177-5230.2013v28n55p164/26624>. Accessed: Dec. 10, 2017. doi: 10.5007/2177-5230.2013v28n55p164.

MCBRIDE, M.B. et al. Concentrations of lead, cadmium and barium in urban garden-grown vegetables: The impact of soil variables. Environ Pollut. v.194, p.254-261, 2014. Available from: $<$ https://www.ncbi.nlm.nih.gov/pmc/articles/pmid/25163429/>. Accessed: Dec. 01, 2017. doi: 10.1016/j.envpol.2014.07.036.

MURDOCH, D.; CHOW, E.D. Ellipse: Functions for drawing ellipses and ellipse-like confidence regions. $\mathbf{R}$ package version 0.3-8. 2013. Available from: <https://CRAN.R-project. org/package=ellipse $>$. Accessed: Jul. 01, 2018. (Electronic publication).

OLIVEIRA, D.L. et al. Plantas nativas do cerrado uma alternativa para fitorremediação. Estudos. v.36, n.11/12, 2009. Available from: $\quad<$ http://seer.pucgoias.edu.br/index.php/estudos/article/ view/670/824>. Accessed: Sept. 09, 2019. doi: 10.18224/est. v36i6.670.

PINTO, R.et al. Environmental viability of urban gardens as spaces for sustainable development. Revista da APH. v.103, n.1722, 2011. Available from: <http://repositorium.sdum.uminho.pt/ handle/1822/15924>. Accessed: Sept. 09, 2019.

R CORE TEAM. R: A language and environment for statistical computing. R Foundation for Statistical Computing, Vienna, Austria. 2017. Available from: <https://www.R-project.org/>. Accessed: Dec. 18, 2017. (Electronic publication).

SUPPI, I.M. et.al. Teores de cobalto e manganês em solos de Santa Catarina. Revista de Ciências Agroveterinárias. v.17, p.579-588. Available from: <file://C:/Users/Cliente/Documents/ Orienta $\%$ C3\%A $7 \%$ C3\%B5es/Willian/artigos/Ciencia\%20 rural/10770-47549-1-PB.pdf> Accessed: Jul, 01, 2018. Doi: $10.5965 / 223811711732018579$.

TSOLOVA, V.T.et al. $\mathrm{Pb}, \mathrm{Cu}$ and $\mathrm{Zn}$ geochemistry in reclaimed soils (Technosols) of Bulgaria. J Geoch Expl. v.144, p.337-344, 2014. Available from: <https://www.sciencedirect.com/science/ article/pii/S0375674214000831>. Accessed: Jul. 01, 2018. doi: 10.1016/j.gexplo.2014.02.019.

UWIZEYIMANA, $\mathrm{H}$. et al. The eco-toxic effects of pesticide and heavy metal mixtures towards earthworms in soil. Environ. Toxicol. Pharmacol. v.55, p.20-29, 2017. Available from: $<$ https:// www.sciencedirect.com/science/article/pii/S138266891730 2089>. Accessed: Jul. 01, 2018. doi: 10.1016/j.etap.2017.08.001.

VIDAL, J.M. et al. Wood preservation in Brasil: historical, current scenario and trends. Cienc. Florest. v.25, n.1, p.257-271, 2015. Available from: $<$ http://www.scielo.br/pdf/cflo/v25n1/01039954-cflo-25-01-00257.pdf>. Accessed: Jun. 30, 2018. doi: 10.1590/1980-509820152505257.

WARD Jr, J.H. Hierarchical Grouping to Optimize an Objective Function, J Am Stat Assoc. v.58, n.301, p.236-244, 2012. Available from: $<$ https://www.tandfonline.com/doi/abs/10.1080/0 1621459.1963.10500845>. Accessed: Jul. 01, 2018. doi: 10.1080 /01621459.1963.10500845. 